\title{
Land in Al Mahmud's Poetry: Central to His Anti-imperialistic Poetics
}

\author{
Salma Begum \\ Department: English Language and Literature \\ International Islamic University Chittagong \\ Dhaka Campus, Bangladesh \\ E-mail: khandokerkarim@yahoo.com
}

Received: 19-03-2014

doi:10.7575/aiac.ijalel.v.3n.5p.120
Accepted: 08-05-2014

Published: 01-09-2014

URL: http://dx.doi.org/10.7575/aiac.ijalel.v.3n.5p.120

\begin{abstract}
Al Mahmud's anti-imperial spirit is evident in his poems resisting the occupation of land by the imperialistic powers throughout the globe. He protests against the aggression of imperial powers at present as well as that happened in the past. Though formal colonies are no more today, colonialism still is there in different form --- in the form of imperialism. Colonies are established for securing wealth from the occupied land. Imperialism launches its power over the land of different country without establishing colonies but its purpose is all the same. Both colonialism and imperialism exploit others' land to enrich themselves. Occupation of land paves the way for imperialism as in the case of British colonialism in Bengal and subsequently in Indian subcontinent. But the launching of imperial power does not go always without resistance on the part of the colonized people. Al Mahmud raises his voice against the evil practice of colonialism and imperialism wherever or whenever he finds them active. He shows this resistance both in national and international perspective. Through his poetics, he protests against the British imperialism in India, particularly in Bengal, and, though colonialism is over, he protests as he sees the imperialistic agents are active in his country to turn her again into a colony. He also protests against imperialistic aggression in different lands of the world like Afghanistan, Palestine etc. In his resistance to imperialism, 'land' becomes his main concern. Here in this article, I have explored those poems that present his strong protest against the occupation of land by colonialism as well as imperialism.
\end{abstract}

Keywords: land, colonialism, imperialism

\section{Introduction}

Al Mahmud, a major poet of Bangla literature, resists imperialism through his poetics. The poet reveals his anti-imperial spirit through his concern for 'land' that becomes instrumental in establishing colonies throughout the globe. He resists imperialism mainly focusing on 'land' that is colonized or on the process of being colonized. He treats the theme of land not only in national perspective but in international perspective too, simultaneously, revealing his love and compassion for all freedom loving people of the world and bringing out his extreme resistance to the imperialistic and colonialist powers of the world.

Al Mahmud grew up in an environment that saw the aftermath of imperial invasion in his country-----all its resources plundered by the British imperialists. The colonial history of his country has a great impact in his mental make-up; he nourishes a strong anti-imperialistic view in his whole life and expresses this in his poetry. Besides the theme of antiimperialism, the themes of woman, love, nature and culture dominate his poetry.

Al Mahmud gives much emphasis on land in his poetry that brings his pure patriotism which also demands resistance to imperialism to save his 'land'(motherland) as well as 'land' of all indigenous people of the world.

\section{Discussion}

Land is inseparable from one's existence. It is very closely related to one's identity being essentially important in the life of a person as well as that of a nation. Because

nations stimulate the people's sense that they are the rightful owners of a specific land. Nations evoke feelings of belonging, home and community for the people and depend upon the invention and performance of histories, traditions and symbols which sustain the people's specific identity continuous between past and present. (John Mcleod,2007, p.74).

So it is clear, the elements of national identity (history, tradition, culture, symbol, language etc.) centre round one main element 'land'. Dispossession of this very land gave rise to liberation movements in colonized countries against colonial rule in the $20^{\text {th }}$ century. Amilcar Cabral in 1970 described the contemporary conflict within several African colonies (as, indeed, it was in many other colonies in other parts of the world previously) specifically as one of 'national liberation in opposition to imperialist domination' (Amilcar Cabral, 'National Liberation and Culture' in Colonial Discourse and 
Post-Colonial Theory, ed. Williams and Chrisman, pp. 54-5 cited in John Mcleod's Beginning Postcolonialism p. 75). For the indigenous people,

place is traditionally not a visual construct, a measurable space or even a topographical system but a tangible location of one's own dreaming, an extension of one's own being. A particular formation like a stream or hill, for instance, may embody a particular dreaming figure, whose location on the dreaming track has a particular significance to a person's own life, 'totem', clan relationship and identity because that person may have been conceived near it. (Bill Ashcroft, Gareth Griffriths, Helen Tiffin, 2004 p.179). The same authors also argue that "effective protection of one's place is radically disabled when that new system (colonizing power) becomes the dominant one" (Bill Ashcroft and others, 2004, p. 180).

Thus protection of one's land and place becomes one with one's existence. The loss of one (land) means the loss of another (identity). As Bill Ashcroft, Gareth Griffiths and Helen Tiffin establish,

how intimately place is involved in the development of identity, how deeply it is involved in history, how deeply implicated it is in the systems of representation-------- language, writing and the creative arts------- that develop in any society but in colonized societies in particular. ( Bill Ashcroft and others, 2004, p. 182)

Colonialism creeps into land by occupying it forcibly from native people and sometimes by settling there with the purpose of plundering its resources, creating markets and controlling it.

The seizing of 'foreign' lands for government and settlement was in part motivated by the desire to create and control markets abroad for western goods, as well as securing the natural resources and labour-power of different lands and peoples at the lowest possible cost. Colonialism was a lucrative commercial operation, bringing wealth and riches to western nations through the economic exploitation of others. It was pursued for economic profit, reward and riches. (Mcleod, 2007, p.7).

Hence, land is instrumental in establishing colonies and colonialism.

So colonialism can be defined as the conquest and control of other people's land and goods. But colonialism in this sense is not merely the expansion of various European powers into Asia, Africa and the Americas from the sixteenth century onwards; it has been a recurrent and widespread feature of human history. (Ania Loomba,1998 p.3)

By 1930s, colonies and ex-colonies covered 84.6 per cent of the land surface of the globe. Only parts of Arabia, Persia, Afghanistan, Mongolia, Tibet, China, Siam and Japan had never been under formal European government. (Fieldhouse 1989:373 cited in Ania Loomba, 1998 p. xiii).

There is an intimate relationship between colonialism and imperialism. Although their forms and systems of operation are different, their purpose is same -------dominating others' territories for securing wealth. Michael Parenti defines imperialism 'as the process whereby the dominant politico-economic interests of one nation expropriate for their own enrichment the land, labor, raw materials and markets of another people'. (Michael Parenti, Against Empire chapter 1, Online).

The range of imperialism is vaster and its system of operation is subtler than colonialism. As Edward Said argues,

"imperialism" means the practice, the theory and the attitudes of a dominating metropolitan centre ruling a distant territory; "colonialism" which is almost always a consequence of imperialism, is the implanting settlements on a distant territory. (Said, 1994 p.8).

Despite the difference in their (colonialism and imperialism) system of operation, their main target is 'land' to plunder its resources. Elleke Boehmer characterizes colonialism as 'the settlement of territory, the exploitation or development of resources and the attempt to govern the indigenous inhabitants of occupied lands'. (Elleke Boehmer,Colonial and Postcolonial Literature, 1995 p. 2 cited in John Mcleod, 2007 p. 8). In this description emphasis has been given on '(a) the settlement of land, (b) the economic relationship at the heart of colonialism, and (c) the unequal relations of power which colonialism constructs'. ( Mcleod, 2007 p. 8).

Imperialism strengthened by military force can strongly dominate, though not directly, the land of other nation. On the other hand, colonialism is directly involved in occupying land or territory of other nation. Colonialism is, rather, one of many faces of imperialism. As Ania Loomba argues, 'In the modern world then, we can distinguish between colonization as the take over of territory of other nation,.... and imperialism as a global system.' (Loomba,1998 p. 6).

So, there is a distinct interrelation among land, colonialism and imperialism and each one is supplementary or supportive to the other. Thus John Mcleod clarifies this------'colonialism is a particular historical manifestation of imperialism, specific to certain places and times'. (Mcleod, 2007 p.8).

Whether it is colonialism or imperialism, its exclusive purpose (as is seen) is to enrich itself by exploiting the colonized territories by any means. So, in colonial countries, imperialism is creeping slowly but aggressively, ultimately, to break down the backbone with a view to pushing the colonized country to an inevitable non-entity as a nation. Nandy perceives this consequence of colonialism in this way-----'the first was relatively simple minded in its focus on the physical conquest of territories, whereas the second was more insidious in its commitment to the conquest and occupation of minds, selves, cultures'. (Ashis Nandy: The Intimate Enemy,1983 cited in Leela Gandhi, 2004 p.15). So colonialism first captures land and then turns the nation of that very land to a non-entity through exploitation and colonialism paves the way for imperialism. So, land becomes their main point of exploitation. 
As a conscious person, a poet cannot remain silent to the crude aggressive form of oppression, repression, cruelty and injustice against humanity. Al-Mahmud, a lover poet, sunk head over ear in passionate, carnal love but ultimately transmits his love for humanities and becomes a strong voice against imperialism, colonialism and all types of powers and agents that strangle humanity in every corner of the world. Al Mahmud protests against the aggression on land by imperialistic power all over the globe. Here in this article, Al Mahmud's those poems are selected in which he resists imperialism focusing on land. The selected poems are-----'No More Plassey', 'I Shan't Go With You, O Motherland', 'Reigning at the Face of Wind', 'For the Motherland', 'Map of Murderers', 'Whose Flag It Is On the Conscienceless Earth', 'Christ is Coming', 'Yaseer Arafat in the Meadows of Mina'. In these poems, Al Mahmud shows how land (motherland) becomes the victim of imperialism either by being colonized or remaining at the risk of being colonized that makes him to resist imperialism for a safe, livable world free of imperialism.

Imperialism crept into Indian sub-continent in 1757 after the defeat of Nawab Siraj-ud-dowla, the last independent Nawab (ruler) of Bengal, at the battle of Plassey. "British rule in India is conventionally described as having begun in 1757. On June $23^{\text {rd }}$ of that year, at the Battle of Plassey, a small village and mango grove between Calcutta and Murshidabad, the forces of the East India Company under Robert Clive defeated the army of Siraj-ud-daulah, the Nawab of Bengal. The 'battle' lasted no more than a few hours, and indeed the outcome of the battle had been decided long before the soldiers came to the battlefield." ( cited from Online).

The effect of the Plassey was far-reaching, so far that it was not perceived even by the conquerors at that time. Actually, Plassey paves the way for the British to set up their colony in Bengal and gradually all over India. In the words of Malleson,

Plassey was a very decisive battle. The effect of it are felt this day by more than two hundred fifty millions of people...... There never was a battle in which the consequences were so vast, so immediate and so permanent. (Malleson, ed. 1885 p.67).

By occupying Bengal territory, the British set up a vast colony and the seed of imperialism was sown in India. As Malleson argues,

from the very morrow of the victory the English became virtual masters of Bengal, Bihar and Orisa........ They were able to extend their authority beyond the Indus, their influence amongst peoples of whose existence even Europe was at the time profoundly ignorant. It was Plassey which made England the greatest Muhammadan power in the world; Plassey which forced her to become one of the main factors in the settlement of the burning Eastern question; Plassey which necessitated the conquest and colonization of the Cape of Good Hope, of the Mauritius, the protectorship over Egypt ; Plassey which gave to the sons of her middle classes the finest field for the development of their talent and industry the world has ever known; to her aristocracy unrivalled opportunities for the display of administrative power; to her merchants and manufacturers customers whose enormous demands almost compensate for the hostile tariffs of her rivals, and ,alas! Even of her colonies; to the skilled artisan remunerative employment; to her people generally a noble feeling of pride in the greatness and glory of the empire of which a little island in the Atlantic is the parent stem, Hindustan the noblest branch; ................ As a victory Plassey was in its consequences, perhaps the greatest ever gained. (Malleson, ed. 1885 pp. 67-68).

But the victory of Plassey was gained not by heroism but by treachery. Malleson says,

but as a battle it is not, my opinion, a matter to be very proud of. In the first place it was not a fair fight." (Malleson, ed. 1885 p. 68). "It was only when treason had done her work, when treason had driven the Nawab from the field, when treason had removed his army from its commanding position, that Clive was able to advance without the certainty of being annihilated. Plassey, then, though a decisive, can never be considered a great battle. (Malleson, ed.1885 p. 69).

In 1757, Mir Jafar, Nawab's commander in general and the chief of traitors, was

conspiring with a foreign people, of whose power he was conscious, to seat himself on the throne ----- for virtually it was a throne ----- of his master. To accomplish this selfish personal end, he hesitates not to become a perjurer of the deepest dye; to doom to a violent death the nephew to whom he had sworn obedience, and to sacrifice the future of his country............... Mir Jafar Khan,.......who sold their three richest provinces (Bengal, Bihar, Orisa) to the English that he might enjoy the mere pageantry of royalty. (Malleson, ed. 1885 pp. 69-70).

Such was the history of Bengal (at present Bangladesh), a history full of treachery and tragedy by which Bengal became the direct victim of colonialism of the British Empire.

So, Plassey becomes a symbol of losing land, liberty and aggression of imperialistic power; it is more recognized as the history of treachery and selfishness that provoked some extremely selfish people to sell the liberty of their country, that actually provoked the British imperialists to expand their colony here. By occupying the land of Bengal, the British got a strong footing to launch colonialism over the subcontinent. So, Al Mahmud views Plassey as a warning, an alarm, a stigma on the nation and a history of disgrace that makes him much conscious about the foreign invaders and internal compradors. Remembering Plassey, he wrote 'No More Plassey' to prevent the tragic repetition of history; to warn his country to be aware of enemies and traitors (as they may sell the country again) and at the same time, to inspire his country people to confront imperialism. The poet says, 
Once again gloom has overcast Bangla's fate,

Recalling that disgrace the nation stands upright

Shame of two centuries is congealed in fair, field and everywhere

Carrying the corpse of Siraj, moves Miran's elephant

$\mathrm{O}$, No more Plassey. Now in Dhaka that procession goes on

Still carrying the flag of grief on elephant's back

And says, forget we not to sacrifice on the wheel of freedom

While pay we the wages of sin, by counting maladies of mischievous mistakes.

(No More Plassey).*

Here the poet recalls the stigma of disgrace (losing liberty) of two centuries resulting from the direct treachery of Mir Jafar. Here 'gloom' indicates the poet's fear of returning of imperialism in his country; Indian sub continent had been a British colony for almost two hundred years from 1757 to 1947; he reminds the readers of 'that disgrace' which lasted for two centuries leaving its signs everywhere, 'fair'(market place), 'field', sparing no place; every corner of life was greatly affected by the British colonialism. So the poet reminds the people of that loss of liberty rebuilding the historical image of the dead body of Siraj being carried away by Miran's (one of the traitors and beneficiaries of Plassey) elephant. Siraj who fought to the last drop of his blood against imperialism, becomes the symbol of freedom and patriotism. Now the poet is determined not to let any more tragedy happen like the Plassey. The poet regrets and warns that still to protect liberty the nation is paying the wage of 'maladies of mischievous mistakes' e,g, the 'sin'(treachery) committed by his forefathers at Plassey. Still 'the procession carrying the flag of grief on the elephant's back' warns people to be aware of and to confront imperialism. Here 'flag of grief' reminds colonial encroachment in Bengal and its lost land and liberty and 'elephant' reminds the tragic treacherous battle of Plassey. Thus his national history haunted by treachery and hypocrisy can not but urge Al Mahmud to raise his voice against all intrigues set against the country. Here his anti-imperialistic spirit flows out from the loss of his motherland.

In the poem "Reining at the face of wind", the poet alarmingly unfolds the present picture of his dear motherland. On his journey of visiting the country, he sees the rows of graves on the bank of river's turning point; the river----to which he is very intimate---- will come just after crossing the forest of trees and birds. Then he comes across hundreds of holes without epitaph, and vultures basking in the sun. Here he stands stunned because his fellows are lying here. He gets fragrance of rose from the martyrs' coffin; then he resumes his journey. After sailing twenty seven years he reaches his well known city, shockingly to him, at present full of foxes 'masked as fighters' shouting and 'masked pleasureseekers' swarming in the inns, poets' composing worst poetry for selfish purpose and 'merchants of maps' wearing intellectual outfit. Finally, he sees a vision-------- hanging Bangladesh (the poet's motherland) as a clipped winged duck, someone like a winter-bird monger, is calling for customers to sell the country at a very cheap rate. In this nice poem, his love, his patriotism, his concern and anxiety for his dear motherland is greatly manifested through his usual imagery of rural and natural objects mainly describing his native land. Symbolic use of images is also evident in presenting the picture of the city, full of selfish, opportunist people. Images like 'vultures spreading wings basking in the sun' indicates aggressive imperialists at ambush; 'foxes shouting in fighter's mask' indicates selfish cunning opportunists whose propaganda silences the citizens; images of 'disguised pleasure-seekers', 'poets' rotten poems full of flattery and smell of bread-n-butter', 'map-merchants wearing intellectual outfit' are closely associated with loveless, selfish compradors who can sell the poet's country just like a bird-monger. The poet's concern reaches its climax in this image---'hanging Bangladesh like a clipped-winged duck, someone is calling customers'-----here duck is obviously a helpless but attractive dish bird and is an accurate reflection of his country ----helpless but very attractive to the imperialists for its resources from time immemorial. Historian Malleson mentions Bengal (now Bangladesh) as one of the three richest provinces of India before British colonialism here (Malleson, ed. 1885 p.70). The natural resources have been attracting the imperial powers of the world from ancient time to the present day. So, Al Mahmud denounces the activities of the Mir Jafars (traitors) that are haunting the country, created by the sub continental aggressive power, always busy in eating up the map of the country as blight. (Amin al Asad, Prekkhon,2007 p. 106)A few lines from the poem:

Reining at the face of wind I reached

Where the citizens are silenced

By the calling of foxes in fighters' mask.

Each of its gates, towers and memorial's known to me.

Masked pleasure seekers are swarming in the inns

Poets' rotten poetry is filled with flattery and smells bread-n-butter.

Map-merchants are wearing intellectual's outfit. And,

Hanging Bangladesh as a clipped winged duck,

Like winter bird-mongers someone is calling the buyers,

'Come, cheap, very cheap.'

(Reining at the Face of Wind/The Second Breach)* 
The poet is frightened at the activity of imperialistic powers in his naturally enriched land. He is doubtful whether the people can save the sovereignty of his land because protecting freedom, he believes, is more difficult than bringing freedom. Because if there is want of a king, it can be fulfilled; if there is political upsurge, that can be pacified; but if the sun of liberty sets once, the rising of it is a matter of luck. (Mir Mosharraf Hossen, Bishad Sindhu, p.349). But next moment he becomes hopeful as he believes, the people being believers in God, will save their mother-like land from all plots and intrigues and then she will emerge as a glorious land. Thus he shows the way to encounter imperialism to save his land. This thought gets outlet in his poem, 'For the Motherland'. Here he offers his best things e, g, his poetry, his blood, his tears, his eyes; offers shoes made by his own skin to his motherland (that he imagines just like a mother) like an ardent loving son. These offerings show his profound patriotism. Then he sympathizes with her as she becomes the target of aggressors. As a deer attracts hunters for its delicious meat; similarly, the resources of his country attracted world's aggressive powers in ages after age. The comparison is exact. Again, he denounces the evil game of treacherous compradors with the country. Al Mahmud utters,

$\mathrm{O}$ my ever wretched mother,

Your very riches become your foe

As the flesh's hostile to a doe.

Nameless, clan less witches busy in dice play

They bet on your very organs,

On which they crave to put on bark to make you a serf for ever.

(For the Motherland/ The Second Breach) *

The poet again says,

Seeing the flight of vultures, I think why

Your green meadows are

Like a banyan tree tainted

With stool of ferocious carnivorous bird?

(For the motherland/ The Second Breach)*

The images of vulture, ferocious, carnivorous birds clearly indicate the activity of aggressive imperialists. Then he glorifies his motherland whose children (people) he encourages to stand erect and to sacrifice everything for her with whom 'nameless, clan less, witches busy in dice play' that is his land has become the playfield of witches (imperialists and compradors) of different type ---big or small----" they bet on your very organs,/ on which they crave to put on bark to make you a serf forever.' That is, traitors and compradors want to make his motherland 'a serf forever' (a country without freedom and sovereignty, in other words, a colony).

The poet's apprehension shows that his country is at the risk or threat of imperialistic power as the traitors and compradors are dangerously active against the interest of the country. They can again convert the country into a colony like its past. So, the poet ardently wants the end of aggression of imperialists and the safety of liberty of his country. Here the themes of land and imperialism, his hope for an anxiety-free land and his fear (embodied in shadows of imperialism) concerning his motherland are juxtaposed.

At the same time, his humanitarian sense tends him to sing for all human beings that are being repressed and suppressed in every corner of the world. As a true lover of freedom and a humanitarian, he cannot remain silent at the plight of the people of Iraq, Afghanistan, Palestine, Kashmir whose people are struggling for their rightful due--- 'Freedom'. A real lover of freedom loves freedom for himself as well as for others equally. Al Mahmud raises his voice in favour of those who are struggling to free their lands from imperialists' aggression all over the world.

Afghanistan has been undergoing U.S. imperialism for a long time. Because 'besides being at a central crossroads of world trade, Afghanistan and Central Asia have considerable newfound oil and mineral wealth. In addition to the area's oil and natural gas fields, Afghanistan itself has large copper deposits, and massive quantities of lithium have been recently discovered.' (John Beacham, Online). This prospect of Afghanistan has attracted the imperialistic powers of the world from ages after age. 'Soviet troops entered Afghanistan in December 1979 and less than a month after the September 11, 2001, attacks, the United States and Britain launched all-out war on October 7, 2001..... For long 10 years, the people of Afghanistan have been living under a brutal U.S./NATO occupation.' (Beacham, Online)

Al Mahmud becomes one with the urge of freedom of an Afghan young man in the poem, 'Map of Murderers' where the young man's ardent love for liberty is evident in his tears. In this poem, Al Mahmud tells about the crude murder happening continuously in the mountainous land of Afghan valley. Afghan people were famous worldwide for their freedom. At present, the poet says, Afghan land has become a place of mistrust as is pointed out in the line, 'today nobody believes the floating white cloud'----even nature here is not trustworthy----------this shows absolute mistrust among the people of this country where 'dead bodies are floating in the fountain'. It is impossible for the people there to believe still that 'the clouds really shed rain'. The once freedom-famous country, Afghanistan, faces this condition because of the crude imperialistic aggression in that land. The poet announces his oneness with the people of this land, haunted by imperialistic powers, very sharply saying that it is the murderers who cannot have any map (land or country) 
as they are hankering after other's land. He feels that Afghanistan now is an 'abducted (invaded and occupied by imperialists) motherland' of all independent people of the world. In the words of the poet:

Once at midnight in this Dhaka a Kabuly young man

Hugging me broke into tears

No, no -Afghanistan's my country, my love---

Shawkat, O pathan young man---say,

Who's country isn't Afghanistan today?

Afghanistan's today the abducted motherland of all free people.

(Map of Murderers/Bakhtier's Horse)*

In the words of Afghan young man ' no, no, Afghanistan is my country, my love', the ardent and profound love for his abducted motherland echoes the poet's innate aspiration for freedom. At the same time, he angrily denounces the imperialistic powers that are creating massacre in Afghan land saying that murderers must have no lands.

The poet again calls for the attention of all peace-loving, freedom-loving and justice-loving people of the world to save a land fallen victim to the cruel aggressors. This burning land in the map of the world is Palestine, burning for ages to get back its lost land. 'In 1948, Israel took over most of what was historical or Mandatory Palestine, dispossessing hundreds of thousands of Palestinians while depopulating 531 Arab villages in the process. Israel has been illegally occupying Palestine since 1967. To put this land occupation in perspective, Israel took $78 \%$ of Palestine in 1948 and took the remaining $22 \%$ in 1967 . Israel with US support, still occupies the areas. With an ally like the United States, Israel is funded militarily, economically, and diplomatically to the extent that it can ignore the call of the world and the call for justice for the Palestinians. The United States enjoys an ally in Israel that is close to these petroleum reserves and near the waterways by which it is transported.' (Carol Baker and Shawn O'hern, Online). In this way, Palestine has become the victim of two imperialist powers----- Israel and US. In the poem 'Yaseer Arafat in the Meadows of Mina', the poet's main concern is land of which liberty is at a stake because of imperialistic aggression. He shows how imperialistic attacks on different lands of the world make its (world's) condition wretched, restless and miserable. He composes a touching poem at the plight of Palestinians. Some lines from the poem 'Yaseer Arafat in the Meadows of Mina':

\author{
My country’s Palestine ----now a trounced town \\ Your first kibla \\ If only once, o you brothers, to Al Kuds your faces you turn, \\ Only once.
}

(Yaseer Arafat in the Meadows of Mina/A One Eyed Deer)*

Here in these lines Yaseer Arafat, the legendary leader of Palestine, ardently appeals to all Muslims whose first 'kibla'( direction of prayer) was Al Kuds, situated in this city. The poet urges all Muslims of the world to be united for the sake of Al Kuds (their first kibla) to confront imperialists of the world. This poem shows the poet's compassion for the people of Palestine who, to rescue their motherland, are struggling, actually alone, against the most powerful imperialists and invaders in the world---the U.S.A and Israel.

Al Mahmud denounces imperialism and visualizes the fall of the dominating power of America. Like the famous English poet Shelly, he is an optimistic poet who believes that the fall of all instruments of oppression is must for the emancipation of the repressed humanity, which he hopes to be very near. Al Mahmud affirms, with the collapse of imperialism the world will be emancipated from its present plight of disaster, aggressive war, invasion in other's country by the only super power of the present world, America, to exploit the resources of others' lands.

The poem 'Nirbibek Prithibir Opar e kar Potaka'(Whose Flag It Is On The Conscienceless Earth) has been written in global perspective. Here is told the tale of a soldier fighting in Kargil, Afghanistan and Palestine------ everywhere he is wounded fatally and all his wounds are on his face, not a single wound on his back. Because, he is a brave fighter fighting to save the lands from imperialists' clutches and never shows his back, that is, never flees away from any battlefield. The poet's heart is bleeding profusely at the deplorable condition of Palestine. He cries,

Perhaps you won't see in a dusty field of Hebron, lying a blooded face of a martyr,

Or in the yard of Al Aqsa, stumbled down a triumphant hero like a child

But no sign of injury on his back.

(Whose Flag it is on the Conscienceless Earth/ A Tale of a Flying Trip)*

Now the fundamental right of freedom and motherland makes the poet identical with the freedom fighters of every militant country. To confront imperialistic aggression, these fighters realize the importance of war, only by which they can survive in the world. Though war is always criticized as something bad, in this present deplorable situation of the world, that very war has become the only means for the repressed to survive.

In reality, war has two sides ---on the one hand, war is the strongest instrument in the hands of the evil aggressive imperialists to encroach other's land and properties; on the other hand, on the face of aggression, it has become the only 
means to survive for the victims, they have no other option but to fight and perish or survive through the process. Al Mahmud, realizing this truth by heart, proclaims his oneness with the latter in his poem :

Say, who wants war in the world except you and me?

Against injustice, this is the last crusade of humanity.

Think, no other way is left for honest people to survive without war.

(Whose Flag is it on the Conscienceless Earth/A Tale of a Flying Trip)*

So to protect the very land of prayer, the soldier must fight. Otherwise, all artists' and all poets' utterance of love will go in vain, because they cannot save their spiritual pride from the imperialist USA bombs without fighting. Bombs do not recognize love, affection, mosque, schools, women, children, wombs, art, literature, culture and civilization. Here USA bombs symbolize all pervasive power of imperialism that occupies others' land including all its resources. In the last stanza of this poem, the poet visualizes that if the imperialistic aggression is not confronted, then a scene is due to come. That is, a colossal USA flag on the conscienceless defeated earth as there is a flag of USA on the lifeless moon. In this way, the imperialistic USA will devour the whole earth if nobody confronts it. By 'USA flag' the poet indicates worldwide irresistible USA imperialism which will occupy (if go unrestrained) the whole world when the world will be devoid of conscience. 'Lifeless moon' could not resist US invasion on its back. Without resistance and reviving the conscience of human being, the world will be just 'lifeless' as the moon and then the imperialistic power (symbolized by US flag) will easily defeat the humanity in the world. Thus the poet ardently appeals to conscience of all humans to rescue and protect the lands of dear world from the occupation of imperialism. Here the theme of land and imperialism takes a universal dimension.

The poet shows his extreme grievance to American rulers who are waging unlimited war against the innocent people of Iraq and Afghanistan quite unjustly; some conscientious people of America also protested against American imperialism and tried to warn and restrain the oppressors by showing placard with the writing "Christ is Coming" which has been caught in a poetic frame under the same title by Al Mahmud. He hoots at the so called Christian who believes in the resurrection of Christ but they have made the earth a Lapland not suitable for human living. Al Mahmud tells in his poem :

In the crowded bus stands of New York or Washington you'll see Fathers of church are standing with placards. On the placard is written 'Christ is coming'........ If he resurrects where is the place in the world for his footing? ......... Only killing is not the truth. Truth is the collapse of the giant that has raised its head towards the heavens. Whatever missiles he may launch towards the womb of mother earth, there will be born humanity. The child will cry from a manger of Bethlehem.

(Christ is Coming/ A Traveler Towards Respite)*

In this prose-poem, the poet tells about the fathers of churches standing with placards (in their hands) at the crowded bus stops of New York or Washington. 'Christ is Coming' is carved on the placards. This happened at the very beginning of the war of Iraq. Both Christians and Muslims believe in the return of Christ in the world again to restore peace. But the poet raises a very reasonable question, if Christ really comes in this war-burnt world, then where is the land for his footing? A safe and free land is surely needed for his step. The poet says that the world sometimes creates self-destructive giants; after some days, they become non-entity but still often the giants' roaring breaches the universe. Yet the humanity is not defeated, still there comes spring in the world and the poets want to hear the cuckoo-sound exactly though their ears get short of hearing because of bombing of war. Here the poet's resistance to imperialism that invades almost the whole world, becomes subtle.

He denounces imperialism at the end of the poem with a hopeful image-------a baby will cry from the manger in a cattle- house of Bethlehem and somewhere in the sky there will appear a new star to trumpet hopeful words in the world. Obviously, here the giant symbolizes the imperialistic power e, g, the USA which, the poet says, wants to devour the universe (sky) too, that is to dominate the earth and space. As a British occupant in Egypt wanted ' to paint the map British red' and if he could, he would 'annex other planets'. (Millin, 1993 p. 138) The birth of Christ, according to Christian belief, shows the coming of Christ to demolish all evils including imperialism, symbolized by the 'baby's cry' and 'the star' and thus the dear earth will again be liable for man. Here also the poet's aim is not any particular land or country but the whole world.

\section{Conclusion}

Thus Al Mahmud appears as a great humanitarian poet who, through his poetics, tries to attract the attention of all peace loving people of the world to rescue all occupied land and to make an end to the domination of all imperialistic powers. Using very common, ordinary and simple words or diction, chosen mostly from nature and common life, he has built a wonderful and extraordinary poetic world where with other subject matters (e.g. women, love, nature) he sings for the freedom of land and humanity that strongly occupies almost whole of his poetic life.

\section{Note:}

* All extracts of poetry have been translated by the author. 


\section{References}

Asad, A. A. (2007). Al Mahmud's Poetry is a Terrible Revolt Against Zionism and Imperialism, Prekhhon, a quarterly literary journal, Al Mahmud volume, July-September and October-December, edited by Kh. Abdul Momen.

Ashcroft, B., Gareth, G., and Helen, T. (2004). Key Concepts in Post-colonial Studies, Routledge.

Gandhi, L. (2004). Postcolonial Theory A Critical Introduction, Oxford University Press.

Hossen, Mir Mosharraf. Bishad Sindhu, Satya Prokash.

Loomba, A. (2001). Colonialism/Postcolonialism, Routledge.

Malleson, G.B.(ed. 1885).Decisive Battles of India from 1746 to 1849, London: W .H. Allen. ISBN 0-554-47620-7, 2 ${ }^{\text {nd }}$ edition.

Mcleod, J. (2007).Beginning Postcolonialism, Routledge.

Said, E. (1994). Culture and Imperialism, Vintage.

Baker, Carol and Shawn O'hern, Imperialism and the Criminalization of the Palestinian People: An Anarchist Analysis , onward newspaper, a source of " anarchist news, opinion, theory and strategy for today" [Online] Available: www.kersplebedeb.com/my stuff/Palestine/onward.html

Beacham, John, (October 6, 2011) Afghanistan and the struggle against imperialism: the truth about the longest war [Online] Available: www.LiberationNews.org-info@pslweb.org

Millin, S. G. (1993) Rhodes, p.138 from Wikipedia, the free encyclopedia.

Parenti, Michael, Against Empire, chapter 1. [Online] Available: http://www michaelparenti.org/imperialism 101.html. http//www.sscnet.ucla.edu/southasia/History/British/Plassey.html . 